\title{
Panel Presentation \\ Professional Education for School Librarianship: The Rutgers University experience
}

\author{
Dr Ross J. Todd \\ School of Communication \& Information \\ Rutgers, The State University \\ 4 Huntington street \\ New Brunswick NJ \\ USA \\ rtodd@rutgers.edu
}

\begin{abstract}
This paper addresses the processes in place to help Master of Library and Information Science (MLIS) students at Rutgers University meet the education requirements for being a school librarian in New Jersey. It outlines both curriculum and certification structures and processes, and identifies a range of support initiatives in place at Rutgers to enable the journey from student to professional.
\end{abstract}

Keywords: Rutgers University, New Jersey department of Education, Support Services, School Librarianship Education.

\section{Country Context}

This paper addresses the processes in place to help Master of Library and Information Science (MLIS) students at Rutgers University meet the education requirements for being a school librarian in New Jersey. In the USA, library and information science education takes place at the Masters degree level, and most are accredited by the American Library Association (ALA). Typically such degrees are labelled Master of Library \& Information Science (MLIS), and school librarianship education is a specialization or track within the MLIS. Currently there are 63 accredited MLIS programs across the USA

(http://www.ala.org/accreditedprograms/directory), and 48 of these provide school librarianship education. Rutgers University is the only provider of the MLIS degree in New Jersey. Also in the USA, a career as a school librarian may be obtained through an educational unit accredited by the National Council for the Accreditation of Teacher Education (NCATE) and recognized by the American Association of School Librarians (AASL). Essentially this means a designated school library track in a master of education degree provided through a faculty of education. In New Jersey, William Patterson University and Rowan University provide this formal education. The advantage of the accredited MLIS degree is that school librarians are also accredited to work in other type of libraries and information agencies, particularly in children and youth services of public libraries, academic libraries, as well as meet state education licensing requirements.

Professional education for school librarians in the USA is also a credentialing and licensing process governed by various state Departments of Education. There are no consistent standards, and certification processes vary considerably from state to state:

$\mathrm{http}: / / w w w . s c h o o l l i b r a r y m o n t h l y . c o m / c e r t / i n d e x . h t m l$. At the same time, there is an Interstate Agreement in place by the National Association of State Directors of Teacher Education and Certification (NASDTEC) which makes it possible for a school librarian who has completed an approved program and/or who holds a certificate or license in one jurisdiction to earn a 
certificate or license in another state or jurisdiction. Receiving states may impose certain special requirements which must be met in a reasonable period of time.

\section{Background to school library education at Rutgers University}

The School of Communication \& Information was created in 1982 with the merger of the Graduate School of Library and Information Studies, the School of Communication Studies, and the Department of Urban Journalism. The journalism and library science programs each had roots in programs established in the 1920s at Rutgers, and the communication program was established during the 1970s. The school is one of the founding members of the iSchool consortium (http://ischools.org).

The MLIS at Rutgers prepares graduates to work in all kinds of libraries and information agencies, and each student works with an academic advisor to determine their individual suite of courses to meet their career and professional aspirations. School librarianship (SL) is one of several articulated specializations within the MLIS degree, together with Digital Libraries, Knowledge Management and Social Media. With these specializations, there is typically a prescribed set of courses, together with optional electives for students to build their coherent specialization.

One of the key leaders in the early years of the school was Professor Mary Gaver, who pioneered both professional education for school librarianship in New Jersey and who undertook some of the earliest state-wide studies of the impact of school libraries on student learning. She concluded: "With the school library literally the heart of the educational program, the students of the school have their best chance to become capable and enthusiastic readers, informed about the world around them, and alive to the limitless possibilities of tomorrow" (Gaver, 1958). In 1983, Professor Carol Kuhlthau joined the school faculty, and began her 30 year research journey developing the "Information Search Process" model which has formed the research foundation for Guided Inquiry". One of Library \& Information Science's most distinguished scholars, Professor Emerita Carol Kuhlthau has played a leading role in the development of the school library program at Rutgers, a program which consistently been ranked \#1 or \#2 in the country, based on national university program rankings provided by the US News and World Report.

The knowledge and skills foundation of the school library specialization is determined by the New Jersey Department of Education, and articulated through its license and credential code for all educators and support personnel who work in NJ public schools:

(http://www.state.nj.us/education/educators/license/). For employment as a school librarian in New Jersey, the Department of Education requires that a candidate must hold a master's degree from a regionally accredited college or university and complete a graduate program approved by the Department. The Department of Education specifies the following for school librarianship education in the state of New Jersey:

- Organization and coordination of school library media programs, resources and instruction to provide a sequential course of study for students;

- Application of learning theory to reading, listening and viewing library media resources;

- Access, evaluation, selection and utilization of library media resources;

- Design and development of multi-media materials;

- Design, development and integration of information literacy skills and the library media program throughout the school curriculum;

- Integration of educational resources and technology throughout the school curriculum;

- Children's literature or young adult literature; 
- Development and implementation of policies and procedures for effective and efficient acquisition, cataloging, processing, circulation, and maintaining equipment and resources to ensure equitable access;

- Development, implementation and evaluation of library media programs to meet educational goals including management of library personnel, resources and facilities;

- Utilization of current and emergent technologies in all phases of school library media programs; and

- Field experience that includes instruction and management. This experience must be completed in a school library media center.

Graduate programs that provide school librarianship education are free to articulate how these requirements are translated into a coherent set of courses. Graduate providers submit detailed documentation on how their programs meet these requirements, and receive approval from the Department of Education to operate a formal program. This approval ensures that on completion of the program, graduates have automatic endorsement by the Department of Education, and Rutgers submits the required documentation on behalf of graduating students.

At Rutgers University, the requirements outlined in the New Jersey Department of Education code are articulated through the following courses shown in Table 1, which have been approved as meeting the state requirements.

Table 1: School Library Specialization in the MLIS, Rutgers University

\begin{tabular}{|l|l|}
\hline Course Title & Description and Comment \\
\hline $\begin{array}{l}\text { Human } \\
\text { Beharmation }\end{array}$ & $\begin{array}{l}\text { This course examines theories of information behaviors and } \\
\text { the study of the information behaviors of people in diverse } \\
\text { contexts, based on existing research-based literature. SL } \\
\text { students can specialize in education context, and tailor study to } \\
\text { specialized groups such as teachers, elementary school } \\
\text { students, urban teens, special needs students. }\end{array}$ \\
\hline $\begin{array}{l}\text { Learning Theory, } \\
\text { Curriculum }\end{array}$ & $\begin{array}{l}\text { This course focuses on the structure and design of school } \\
\text { library programs by examining constructivist learning theories, } \\
\text { research that that informs instruction, inquiry-based pedagogy, } \\
\text { curriculum standards, as well as current trends in information } \\
\text { technology, outcomes based education and evidence-based } \\
\text { practice. The focus is Guided Inquiry and the design of team- } \\
\text { based instruction integrating NJ curriculum standards, } \\
\text { Common Core State Standards, and AASL learning standards. }\end{array}$ \\
\hline $\begin{array}{l}\text { Principles of } \\
\text { Searching }\end{array}$ & $\begin{array}{l}\text { This course focuses on the study the human-human and } \\
\text { human-computer interaction as relevant to effective searching } \\
\text { of contemporary information resources on behalf of users } \\
\text { seeking information. The course enables SL students to design }\end{array}$ \\
\hline $\begin{array}{l}\text { Cataloguing and } \\
\text { Classification }\end{array}$ & $\begin{array}{l}\text { This course focuses on the theories, systems, and practices of } \\
\text { cataloging and classification. This includes: AACR2R, } \\
\text { MARC21 format, Dublin Core Metadata Set, Dewey Decimal } \\
\text { and Library of Congress Classifications, and Library of } \\
\text { Congress Subject Headings. }\end{array}$ \\
\hline $\begin{array}{l}\text { This course focuses on the full range of information resources } \\
\text { studied and used in applied contexts, placing emphasis on } \\
\text { access to information through reference tools and the use of } \\
\text { information by learners. Emphasis placed on research tools, } \\
\text { databases, information services, policy development, digital }\end{array}$ \\
\hline Services \&
\end{tabular}




\begin{tabular}{|c|c|}
\hline & and resource evaluation. \\
\hline $\begin{array}{l}\text { Materials for } \\
\text { Children }\end{array}$ & $\begin{array}{l}\text { This course focuses on the examination and evaluation of both } \\
\text { print and digital materials for children, birth to age twelve. } \\
\text { Emphasis is on literary and artistic interpretations of picture } \\
\text { books and other visual media, including the World Wide Web. }\end{array}$ \\
\hline $\begin{array}{l}\text { Materials for } \\
\text { Young Adults }\end{array}$ & $\begin{array}{l}\text { This course focuses on the evaluation and selection of } \\
\text { materials based on literary criteria and the biological, } \\
\text { sociocultural, psychological, and developmental characteristics } \\
\text { of young adults. Emphasis is placed on gender-fair and } \\
\text { multicultural materials and the attitudes, interests, problems, } \\
\text { and opportunities of young adults in contemporary society. }\end{array}$ \\
\hline $\begin{array}{l}\text { Information } \\
\text { Technology for } \\
\text { Libraries and } \\
\text { Information } \\
\text { Agencies }\end{array}$ & $\begin{array}{l}\text { This course introduces students to key concepts in Web } \\
\text { Technologies (xHTML, CSS), Web Programming (JavaScript, } \\
\text { PHP, Python) and Data Management (XML, MySQL). Students } \\
\text { also learn how to use and evaluate Web Services, Social } \\
\text { Software and Open Source Software tools. Students develop } \\
\text { applications targeted to their area of professional practice, } \\
\text { particularly developing school libraries as digital libraries. }\end{array}$ \\
\hline $\begin{array}{l}\text { Managing School } \\
\text { Library Programs }\end{array}$ & $\begin{array}{l}\text { This course examines the management of school library } \\
\text { programs, including instruction, collection development and } \\
\text { access, staffing, facilities, and budgeting and advocacy, using } \\
\text { a case study approach to strategic planning and needs } \\
\text { assessment. The theoretical strand provides background in } \\
\text { management theory as it relates to school libraries. }\end{array}$ \\
\hline $\begin{array}{l}\text { Field Experience } \\
\text { for School } \\
\text { Libraries }\end{array}$ & $\begin{array}{l}\text { This course requires a minimum of } 150 \text { hours of supervised } \\
\text { professional work in a school library. Students are expected to } \\
\text { design, implement and evaluate a Guided Inquiry instructional } \\
\text { unit as part of their experience. }\end{array}$ \\
\hline $\begin{array}{l}\text { Multimedia } \\
\text { Production }\end{array}$ & $\begin{array}{l}\text { This course focuses on the design and production of integrated } \\
\text { media resources for libraries, media centers, and information } \\
\text { systems and other informational applications. It examines and } \\
\text { critiques current uses of new media and provides skills in user- } \\
\text { centered multimedia design, and developing of libraries as } \\
\text { vibrant digital repositories. }\end{array}$ \\
\hline \multicolumn{2}{|c|}{$\begin{array}{l}\text { Elective Courses } \\
\text { Students can choose one or more elective courses made available to all MLIS } \\
\text { students } \\
\text { - Designing User-Centered Services } \\
\text { - Understanding, Designing, and Building Social Media } \\
\text { - Children's and Youth Services } \\
\text { - Planning Outreach Services } \\
\text { - Social History of Children's Literature } \\
\text { - Gender and Culture in Children's Picture Books } \\
\text { - Reading Interests of Adults } \\
\text { - Research Methods } \\
\text { - Digital Libraries } \\
\text { - Collection Development }\end{array}$} \\
\hline
\end{tabular}

All school library certification courses are delivered in both on-campus and online modes. The courses "Learning Theory, Media and Curriculum", and "Managing School Library Programs" are the only courses directly targeted to SL students. In all other courses, SL students are integrated with other library specializations, and assessment tasks are tailored to enable students to situate their learning within the specialized context, such as school 
libraries. At the same time, SL students situate their specialized context within the broader spectrum of library and information agencies, building stronger networks and interconnections with a range of information services which can support their roles.

While the majority of our students come into the School Librarianship program with $\mathrm{NJ}$ teacher certification, prospective school librarians who do not have teacher certification are expected to also complete a minimum of 3 formal semester courses in educational theory, curriculum design and integration, teaching methodology, student/learning development, and behavior management. Following completion of their certification as school librarians, once in the workplace, school librarians must also complete a year-long school-based residency program in a school library, under the supervision of a school administrator, principal or district school library supervisor. This supervised residency includes professional experiences in the delivery of instruction in information literacy skills and the development and coordination of school library media programs and resources. In addition, the residency includes the delivery of instruction in the evaluation, selection, organization, distribution, creation, and utilization of school library media. Upon completion of the year-long residency period, the supervisor completes a comprehensive evaluation report on the candidate's performance based on the candidate's ability to complete the job duties pursuant to the code, and recommends issuance of a standard educational services certificate with a SLMS endorsement; or, failing that, addresses a path forward for meeting full certification requirements.

\section{Support services}

A number of processes are also in place at Rutgers University to support our school library students during their MLIS studies and to prepare them for professional work as school librarians, and to ensure their employability as dynamic school librarians. These are outlined below.

(1) Responsive curriculum design: We recognize that the educational and technological landscapes are rapidly changing, and there is need to be proactive in course design so that graduate are on the leading edge of instructional initiatives. For example, the adoption of the Common Core State Standards (CCSS) Initiative in New Jersey opens a core role of school librarians. The CCSS places considerable emphasis on evaluation and engagement with information texts across multiple media, engaging with strong and thorough textual evidence to support analysis, analyzing and synthesizing multiple interpretations, writing arguments to support claims with clear reasons and relevant evidence, using technology tools to produce and publish writing and other forms of idea representation and showing how themes interact and build on one another to produce a complex account. Within months of the NJ department of Education announcing its involvement in CCSS, we were able to mount an elective course titled: "Nonfiction for the Common Core" to develop SL capabilities in engaging with the Common Core initiative, and to situate the role of the school librarian as an integral part of the CCSS rollout.

(2) Connecting professional education to practice: Through a series of professional Colloquiums lead by leading practitioners, students engage in lectures, presentations and discussions that highlight current and recurring issues. Over the last couple of years, these have included themes such as digital citizenship, building social capital, digital curation, publishing trends, copyright, and information policy. These are typically held on campus, with digital conferencing for online students to actively participate.

(3) RASL: Rutgers Association of School Librarians. This student-led association has monthly meetings bringing in leading school librarians to provide hands-on advice, for example, negotiating the job market, interviewing in schools, managing the first 6 months on 
the job; building community networks; developing leadership capacity, dealing with district policies and procedures, building and maintaining collections, and the like.

(4) Student Advising: all students are assigned an individual academic adviser; dedicated administrative staff in the school track their program progress and file certification requirements with the New Jersey Department of Education.

(5) Online help support 24/7 via phone or web: Students in the online program have $24 / 7$ technical support when they encounter technical problems such as access to course shells, dropboxes, certain areas of courses not viewable.

(6) Scholarship support: A series of scholarships and endowments are available exclusively to school library students to provide financial support for their studies. Depending on the donor specifications, these are based on both financial need and academic progress.

(7) Field experience: As part of their state certification requirement, all SL students must undertake 150 hours of professional field experience in a school, under the direct supervision of a certified school librarian. A dedicated Field Experience Coordinator works individually with all SL students to guide their choice of placement, negotiate district policies, facilitate the required government background checks, and evaluate student progress with the field experience.

(8) CiSSL: The Center for International Scholarship in School Libraries provides financial support for some SL students to work as administrative assistants to CiSSL scholars. CiSSL also runs events for the professional community, and students play a role in the organization and operation of these events.

(9) NJASL: New Jersey Association of School Librarianship provides highly discounted annual memberships for the association to Rutgers SL students ( $\$ 25$ per year), and awards an annual scholarship award to support conference attendance and to work as trainee conference leaders.

(10) Portfolio Development: All MLIS students complete an ePortfolio Capstone, and SL students, working with their academic advisor, develop an ePortfolio showcasing their academic accomplishments as well as build a professional ePortfolio focusing on career goals and objectives using a range of digital tools, with examples and evidences of initiatives and competencies.

(11) Career Fair. The School of communication \& Information hosts an annual Careers Fair, involving teams of leading professionals from all of the LIS sectors. These teams review individual students' resumes and ePortfolios and provide panel discussions on engaging with the job market.

(12) Careers Portal: Schools and districts across New Jersey recognized Rutgers a leader in the provision of SL education, and over the years, employment opportunities are fed into the Rutgers Careers Portal and positions and other opportunities are directly advertised to students from the MLIS listerv.

(13) Program Associates: This is a formal advisory group that meets twice-yearly to provide insights, advice and feedback on the MLIS program. The President of the New Jersey Association of School Librarians is a member of this committee. 
In summary, the processes in place to help Master of Library and Information Science (MLIS) students at Rutgers University meet the education requirements for being a school librarian in New Jersey are a coordinated and interconnected set of program, system and professional dynamics. These involve the New Jersey Department of Education which sets the knowledge and skills requirements for state certification as a school librarian, the program specialization at Rutgers University and its ongoing revision and development to be abreast of key educational developments and initiatives, the support services provided in multiple ways to ensure timely completion of the MLIS and to track students' progress; and professional services provided to enable a strong transition for masters student to leading school library professional.

\section{References}

Gaver, M. (1958). Every child needs a school library. Chicago, ALA.

\section{Biographical note}

Dr Ross Todd is associate professor in the School of Communication and Information at Rutgers University. He has responsibility for the school library specialization in the school's MLIS program. He is Director of the Center for International Scholarship in School Libraries (CISSL), at Rutgers University. His scholarly work primarily focuses on understanding how children learn and build new knowledge from information; how school librarians and classroom teachers can more effectively empower student learning; and how the development of information and critical literacies through guided inquiry and constructivist learning approaches lead to deep knowledge and deep understanding. 